\title{
Development of Catalysts for the Hydrogenation of the Aromatic Ring in Gasolines
}

\author{
L. R. Sassykova* \\ al-Farabi Kazakh National University, \\ Faculty of Chemistry and Chemical Technology, \\ 71, al-Farabi Ave., Almaty, Kazakhstan 050040
}

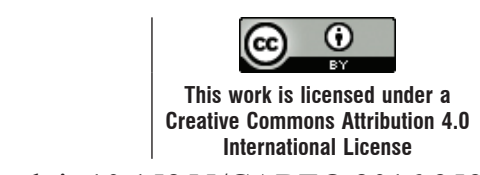

doi: 10.15255/CABEQ.2016.959

Original scientific paper

Received: July 28, 2016

Accepted: November 26, 2017

Liquid-phase hydrogenation of benzene ring in gasoline fractions of Atyrau Oil Refinery LLP (Kazakhstan) was studied. Mono- and bimetallic catalysts on the basis of platinum metals on various carriers were synthesized. It was succeeded to reduce aromatic compounds content (totally) for "hydrogenate" fraction to $0.6-4.64 \%$ (in initial gasoline $-11.2 \%$ ), and also to completely exclude the content of benzene from final sample or to reduce its quantity to $0.06 \%$ (in the initial sample $-2.54 \%$ ). For the fraction "stable catalysate" benzene content was reduced to $0.15 \mathrm{wt}$ \% (in the initial sample $5.17 \%$ wt.), benzene conversion - $97 \%$. For the fraction "hydrogenate" aromatic compounds content was decreased from 13.70 to $2.26 \mathrm{wt} \%$. For the "stable catalysate" an amount of aromatic compounds was reduced from 51.5 to $22.96 \mathrm{wt} \%$. At catalytic hydrodearomatization of the gasoline fractions octane number was not reduced.

Keywords:

hydrogenation, catalysts, aromatic ring, gasoline

\section{Introduction}

The modern requirements for the ecological properties of automotive fuels have highlighted the need for research and development of technologies and active catalytic systems for synthesis of high-octane fuels with low content of aromatic compounds ${ }^{1-5}$. The hydrocarbon composition significantly affects the quality of fuels. Enhanced content of aromatic compounds causes decreased speed, and completeness of fuel combustion increases the carburization that finally promotes deterioration of the ecological situation in the world.

Decrease in the content of aromatic hydrocarbons in oils and oil products can be achieved, in particular, by hydrogenation of aromatic hydrocarbons, which leads to changes in the chemical structure of hydrocarbons in the given direction ${ }^{6,7}$.

The research of synthesis of catalytic systems with high activity and selectivity and development of technology of hydrogenation of a benzene ring in fuels, in particular hydrogenation of benzene in gasolines, is perspective and relevant ${ }^{8,9}$.

The aim of this work was the synthesis of efficient mono- and bimetallic supported catalysts, and their testing in the process of selective liquid-phase hydrogenation of the aromatic rings in gasoline fractions of Atyrau Refinery LLP (Kazakhstan) at elevated pressure.

"Corresponding author: larissa.rav@mail.ru

\section{Experimental}

The liquid phase hydrogenation was carried out at high pressure kinetic installation (KIHP) and in an autoclave - apparatus for processes at elevated pressure with heating of company "Amar Equipment Ltd", India production (Figs. 1, 2). In this work, the supported -mono- and bimetallic catalysts on the basis of metals of VIII group with additives using an earlier developed technique ${ }^{10,11}$ were synthesized. Samples of catalysts were prepared with various atomic ratios of metals - from 9:1 to 1:9. For synthesis of catalysts, the aqueous solutions of salts of VIII group metals $\left(\mathrm{PdCl}_{2}, \mathrm{RhCl}_{3} \cdot 3 \mathrm{H}_{2} \mathrm{O}\right.$, $\mathrm{H}_{2} \mathrm{PtCl}_{6} \cdot 6 \mathrm{H}_{2} \mathrm{O}, \mathrm{RuOHCl}_{3}$ ) were used. Solutions of the corresponding compounds were inflicted with the adsorption method on the prepared carriers by slow dropwise addition from a dropping funnel. The experiment and analysis of the initial compounds and products of hydrogenation were carried out using technique ${ }^{12-14}$. Reactions were carried out with electrolytic hydrogen from the balloon (99.8 \%); for the gas liquid chromatography (GLC) helium $(99.992 \%)$ was used from a cylinder. Chemically pure alcohols and hexane were used as solvents. The methods of gas-liquid chromatography (GLC), iodometric titration, and method of aniline point were used for analysis of the initial compounds and reaction products ${ }^{15-18}$. The gas-liquid Chromatograph Crystal M 4000 (Yoshkar-Ola, Russia) with a capillary column Zebron ZB-1 (30 mL x 0.53 mmID x 


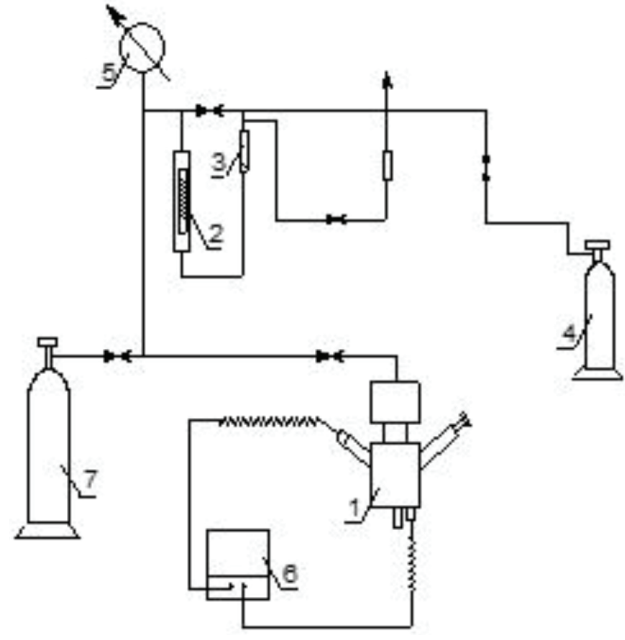

Fig. 1 - Kinetic high-pressure installation; 1 - improved autoclave Vishnevsky; 2 - measuring burette; 3 - equalizing capacitance; 4 - buffer capacitance; 5 - exemplary manometer; 6 - IRT; 7 - hydrogen balloon

$5.00 \mu \mathrm{m}$, liquid phase $-100 \%$ dimethylsiloxane, gas-carrier-helium, detector - flame and ionization; and gas-liquid Chromatograph "3700": a packed column with a stationary phase of $15 \%$ Carbowax -1500 were used. Total analysis time is equal to 90-120 min. The physical and chemical research techniques of catalysts: BET, electron microscopy, $\mathrm{X}$-ray diffraction, infrared spectroscopic analysis method on "Specord JR-75" and "UR-20" were also used. On the basis of the obtained data on the specific surface area and the true pore volume, the average pore diameter was calculated. Electron microscopy of the samples was studied with the electron microscope EM-125K using the method of multistage replicas with extraction with application of a microdiffraction (increase in 160 thousand), and also on a scanning (raster) microscope Jeol JSM-6610 (Japan). The results of experiments on the reduction of hydrocarbons and gasoline fractions are presented in the form of curves on a rectangular coordinate system, where the horizontal axis represents the duration of a process in min, along the axis of the ordinates - volume of hydrogen absorbed per $\mathrm{cm}^{3}$.

Table 1 - Hydrogenation of "hydrogenate" pos.11-SN-002 $K U G B D$ on $0.5 \%$ monometallic catalysts supported on $\mathrm{Al}_{2} \mathrm{O}_{3}$ Process conditions: amount of catalyst $-2.0 \mathrm{~g}$; gasoline volume $-30 \mathrm{~mL}, p_{\mathrm{H}_{2}}=2.0 \mathrm{MPa}, \mathrm{T}=298 \mathrm{~K}$

\begin{tabular}{c|c|c|c|c}
\hline \multirow{2}{*}{ Catalyst } & \multicolumn{2}{|c|}{ Benzene content, \% } & \multicolumn{2}{c}{$\begin{array}{c}\text { Aromatic compounds } \\
\text { content (total), \% }\end{array}$} \\
\cline { 2 - 5 } & $\begin{array}{c}\text { Initial } \\
\text { test }\end{array}$ & $\begin{array}{c}\text { After } \\
\text { hydrogenation }\end{array}$ & $\begin{array}{c}\text { Initial } \\
\text { test }\end{array}$ & $\begin{array}{c}\text { After } \\
\text { hydrogenation }\end{array}$ \\
\hline $\mathrm{Rh}$ & 2.54 & 0.06 & 11.12 & 3.05 \\
$\mathrm{Pt}$ & 2.54 & 0.05 & 11.12 & 2.30 \\
$\mathrm{Pd}$ & 2.54 & 0.03 & 11.12 & 2.63 \\
\hline
\end{tabular}

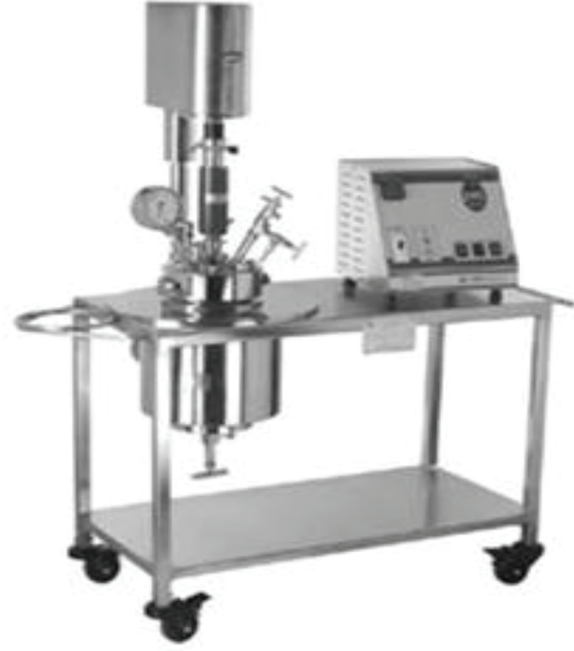

Fig. 2 - General view of installation with the autoclave AmarEquipments Pvt. Ltd. (India)

Hydrogenation was carried out of 2 gasoline fractions: 1 - "hydrogenate" position 11 , the SN002 KU HBD, 2 - "stable catalysate", which were obtained from the LLP "Atyrau Oil Refinery" (Kazakhstan). The reaction was studied at temperatures 298-373 K and hydrogen pressure 2.0-4.0 $\mathrm{MPa}$.

\section{Results and discussion}

\section{Hydrogenation of gasoline fractions}

Data on hydrogenation of a sample of gasoline "hydrogenate" position 11-SN-002 KU GBD on monometallic catalysts $(2.0 \mathrm{~g})$ in isopropanol are presented in Table 1. The experimental results show that $\mathrm{Pt} / \mathrm{Al}_{2} \mathrm{O}_{3}$ catalyst is the most active catalyst with respect to the aromatic hydrocarbon. In the sample after hydrogenation on this catalyst, the content of aromatic compounds is significantly reduced (from $11.2 \%$ in the original sample to $2.30 \%$ - after the experiment). By lowering of benzene content with the most active catalyst $-\mathrm{Pd} / \mathrm{Al}_{2} \mathrm{O}_{3}$, after hydrogenation, the benzene content decreased from $2.54 \%$ to $0.03 \%$. Hydrogenation of the gasoline fraction "hydrogenate" pos.11-SN-002 KU GBD on the bimetallic catalysts was investigated (Table 2). The experimental results show that bimetallic catalysts are more active in the hydrogenation of gasoline than monometallic. Benzene content was reduced from $2.54 \%$ to $0.03-0 \%$. At $3.0 \mathrm{MPa}$ and $298 \mathrm{~K}$, the most active catalyst was Rh-Pt(1:1)/ $\mathrm{Al}_{2} \mathrm{O}_{3}$, in the samples after completion of hydrogenation, benzene was absent. The results of experiment show that, irrespective of the amount of hydrogenated gasoline $(5.0$ and $30.0 \mathrm{~mL})$, in the test after hydrogenation, the content of aromatic com- 
Table 2 - Hydrogenation of the gasoline fraction "hydrogenate" pos.11-SN-002 KU GBD on the bimetallic catalysts, supported on $\mathrm{Al}_{2} \mathrm{O}_{3}$

\begin{tabular}{l|c|c|c|c|c|c|c|c}
\hline \multirow{2}{*}{ Catalyst } & \multirow{2}{*}{$\begin{array}{c}\text { Benzene } \\
\text { volume } \\
\text { mL }\end{array}$} & \multicolumn{3}{|c|}{ Reaction conditions } & \multicolumn{3}{c|}{ Benzene content, \% } & \multicolumn{2}{c}{$\begin{array}{c}\text { Aromatic compounds content } \\
\text { (total), \% }\end{array}$} \\
\cline { 3 - 10 } & Catalyst amount, g & $p, \mathrm{MPa}$ & $T, \mathrm{~K}$ & Initial test & After hydrogenation & Initial test & After hydrogenation \\
\hline Rh-Pt (1:1) & 30.0 & 2.0 & 3.0 & 298 & 2.54 & 0 & 11.12 & 2.30 \\
Pd-Pt (1:1) & 30.0 & 2.0 & 3.0 & 298 & 2.54 & 0 & 11.12 & 2.56 \\
Rh-Pd (1:1) & 30.0 & 2.0 & 3.0 & 298 & 2.54 & 0.01 & 11.12 & 3.98 \\
Ru-Pd (1:1) & 30.0 & 2.0 & 3.0 & 298 & 2.54 & 0.03 & 11.12 & 5.56 \\
Pd-Pt (1:1) & 5.0 & 0.5 & 2.5 & 298 & 2.54 & - & 11.12 & 2.63 \\
Rh-Pt (1:1) & 5.0 & 0.5 & 2.5 & 373 & 2.54 & 0.01 & 11.12 & 2.20 \\
\hline
\end{tabular}

pounds is significantly reduced (from $11.2 \%$ in initial test to $2.3-3.2 \%$ in the test after hydrogenation), and, the more the amount of catalyst (2.0 and $0.5 \mathrm{~g}$ catalyst), the lower content of aromatics (in total) and benzene. At hydrogenation under hydrogen pressure of 2.0 MPa in the final samples after hydrogenation no traces of benzene were found. The greatest activity in the hydrogenation of gasoline were shown by bimetallic Pt-Rh-catalysts on various carriers $\left(\gamma+\chi-\mathrm{Al}_{2} \mathrm{O}_{3}, \gamma-\mathrm{Al}_{2} \mathrm{O}_{3}, \mathrm{SiO}_{2}\right)$. Fig. 3 demonstrates the kinetic curves of gasoline hydrogenation ("hydrogenate" pos.11-SN-002 KU GBD) in hexane at $3.0 \mathrm{MPa}$ and $298 \mathrm{~K}$. The most active catalyst was the catalyst on the basis of Rh-Pd and $\mathrm{Rh}-\mathrm{Pt}$, while at the same time, the high level of hydrogen absorption in the first minutes of the process was noticed. In all cases, there was a decrease (or complete disappearance) of benzene in the final samples, as well as reduction in aromatic compounds content after the hydrogenation process.

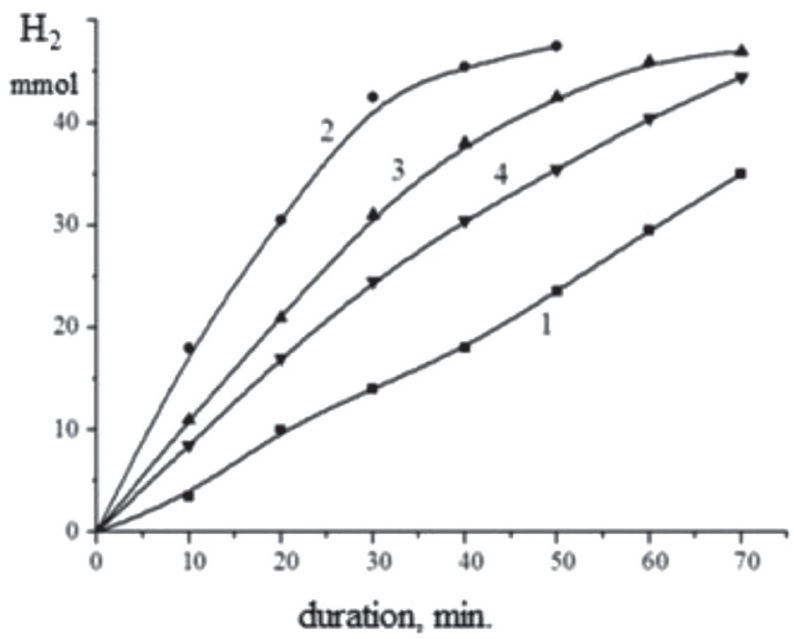

Fig. 3 - Hydrogenation of benzene fraction "hydrogenate" pos.11-SN-002 KU GBD in hexane at 3.0 MPa and $298 \mathrm{~K} ; 1$ $R h / A l_{2} O_{3}, 2-P t-P d(1: 1) / A l_{2} O_{3}, 3-R h-P t(9: 1) / A_{2} O_{3}, 4-R h$ $\mathrm{Pd} / \mathrm{Al}_{2} \mathrm{O}_{3}$
Hydrogenation of 2nd-gasoline sample ("stable catalysate") was performed on $\mathrm{Rd}-\mathrm{Ru}(1: 1) / \mathrm{Al}_{2} \mathrm{O}_{3}$, $\mathrm{Rh}-\mathrm{Pt}(90: 10) / \mathrm{Al}_{2} \mathrm{O}_{3}, \mathrm{Rd}-\mathrm{Ru}(1: 1) / \mathrm{Al}_{2} \mathrm{O}_{3}, \mathrm{Rh} / \mathrm{Al}_{2} \mathrm{O}_{3}$. The process was carried out in iso-propanol and hexane, process temperatures - 298-333 K and hydrogen pressure - 2.5-4.0 $\mathrm{MPa}$. Irrespective of the composition of the catalyst, in the final test after hydrogenation, the content of both benzene and aromatic compounds had decreased (Table 3). Thus, at hydrogenation of gasoline on $\mathrm{Rh} / \mathrm{Al}_{2} \mathrm{O}_{3}$, the yield of benzene after the experiment was $3.80 \%$ (in the initial sample $-5.17 \%$ ), of aromatic compounds $30.5 \%$ (in the initial sample $-51.5 \%$ ). The greatest decrease in benzene content (to $3.15 \%$ in the final sample) was found for the catalyst composition Rd$\mathrm{Ru}(1: 1) /\left(\mathrm{Al}_{2} \mathrm{O}_{3}\right)$, and of aromatic compounds - for the catalyst $5 \% \mathrm{Rh}-\mathrm{Pt}(90: 10) / \mathrm{Al}_{2} \mathrm{O}_{3}$ (to $18.2-19.6 \%$ in the final sample).

At hydrogenation of the 2nd sample of gasoline on the catalyst Rh-Pt $(90: 10) / \mathrm{Al}_{2} \mathrm{O}_{3}$ the process of temperature increase from $298 \mathrm{~K}$ to $333 \mathrm{~K}$ had not reduced the benzene and aromatic compounds content. Thus, at $298 \mathrm{~K}$, the content of benzene and aromatic compounds in the final sample was equal to $3.73 \%$ and $19.1 \%$, respectively, and at $60{ }^{\circ} \mathrm{C}$ $3.95 \%$ and $19.5 \%$, respectively. This was accompanied by an increase in process speed by 1.2 times, and a decrease in hydrogenation duration (from 70 $\min$ to $54 \mathrm{~min}$ ). Increasing the hydrogen pressure from 3.0 $\mathrm{MPa}$ to $4.0 \mathrm{MPa}$ led to a decrease in benzene content (from 3.73 to $3.4 \%$ ), in aromatic compounds (from 19.1 to $18.2 \%$, respectively).

Figs. 4 and 5 show a typical chromatogram of gasoline fraction before the reaction (Fig. 4) and after hydrogenation (Fig. 5) obtained by GLC method under the conditions of the analysis according to GOST R 52714-2007. It is obvious that after hydrogenation the benzene peak is absent. For Rh-Pt (90:10)/ $/ \mathrm{Al}_{2} \mathrm{O}_{3}$ in the interval of hydrogen pressure $0.5-5.0 \mathrm{MPa}$ an order of reaction on hydrogen is equal to 1 (according to logarithmic dependence of a speed on a pressure). The apparent activation en- 
Table 3 -Hydrogenation of "stable catalysate" on the bimetallic catalysts in hexane

\begin{tabular}{l|c|c|c|c|c|cc}
\hline \multirow{2}{*}{$\begin{array}{l}\text { Catalyst } \\
\end{array}$} & \multicolumn{3}{|c|}{ Conditions } & \multicolumn{3}{c|}{ Benzene content, \% } & \multicolumn{2}{c}{$\begin{array}{c}\text { Aromatic compounds content } \\
\text { (total), \% }\end{array}$} \\
\cline { 2 - 9 } & Catalyst amount, g & $p, \mathrm{MPa}$ & $T, \mathrm{~K}$ & Initial test & After hydrogenation & Initial test & After hydrogenation \\
\hline $5 \% \mathrm{Rh} / \mathrm{Al}_{2} \mathrm{O}_{3}$ & 2 & 3.0 & 298 & 5.17 & 3.80 & 51.5 & 30.5 \\
$5 \% \mathrm{Rd}-\mathrm{Ru}(1: 1) / \mathrm{Al}_{2} \mathrm{O}_{3}$ & 2 & 3.0 & 298 & 5.17 & 3.15 & 51.5 & 29.9 \\
$5 \% \mathrm{Rh}-\mathrm{Pt}(90: 10) / \mathrm{Al}_{2} \mathrm{O}_{3}$ & 2 & 3.0 & 298 & 5.17 & 3.73 & 51.5 & 19.1 \\
$5 \% \mathrm{Rh}-\mathrm{Pt}(90: 10) / \mathrm{Al}_{2} \mathrm{O}_{3}$ & 2 & 3.0 & 313 & 5.17 & 4.0 & 51.5 & 19.6 \\
$5 \% \mathrm{Rh}-\mathrm{Pt}(90: 10) / \mathrm{Al}_{2} \mathrm{O}_{3}$ & 2 & 3.0 & 333 & 5.17 & 3.95 & 51.5 & 19.5 \\
$5 \% \mathrm{Rh}-\mathrm{Pt}(90: 10) / \mathrm{Al}_{2} \mathrm{O}_{3}$ & 2 & 4.0 & 298 & 5.17 & 3.4 & 51.5 & 18.2 \\
$5 \% \mathrm{Rh}-\mathrm{Pt}(90: 10) / \mathrm{SiO}_{2}$ & 2 & 3.0 & 298 & 5.17 & 3.28 & 51.5 & 20.0 \\
\hline
\end{tabular}

ergy of the hydrogenation of the 2nd sample of gasoline at temperatures $298-333 \mathrm{~K}$ is $40.8 \mathrm{~kJ} \mathrm{~mol}^{-1}$. Thus, the research results suggest that at 2.0-3.0 MPa and 298-373 $\mathrm{K}$, catalytic hydrogenation allows the reduction of aromatic compounds content (totally) for the "hydrogenate" fraction to $0.6-$ $4.64 \%$ (in initial gasoline -11.2 $\%$, and complete exclusion of benzene with $100 \%$ conversion, or reduction of its quantity to 0.06 $\%$ (in initial sample - $2.54 \%$ ). For the "stable catalysate" fraction, the benzene content in its initial state was $5.17 \mathrm{wt} \%$, and after the reaction, the benzene content was 0.15 wt. $\%$, i.e. the benzene conversion was equal to $97.0 \%$. Data on the composition of the group of organic substances in gasolines indicate that for fraction "hydrogenate", the aromatic compound content is reduced from $13.70 \mathrm{wt} . \%$ to $2.26 \mathrm{wt} . \%$. For the "stable catalysate", the quantity of aromatic compounds was reduced from 51.5 wt. $\%$ to 22.96 wt.\%. It should be noted that the quantity of olefins reduced by almost two-fold, and isoparaffins content increased from 35.79 wt. $\%$ to 44.26 wt. $\%$, which is favorable for the octane number. In addition, the isoparaffins content was also increased from 29.57 wt. $\%$ to $51.75 \mathrm{wt} . \%$.

Independent Centre of Expertise of oil products "ORGANIC" (Almaty, Kazakhstan) analyzed the gasoline fractions, which had

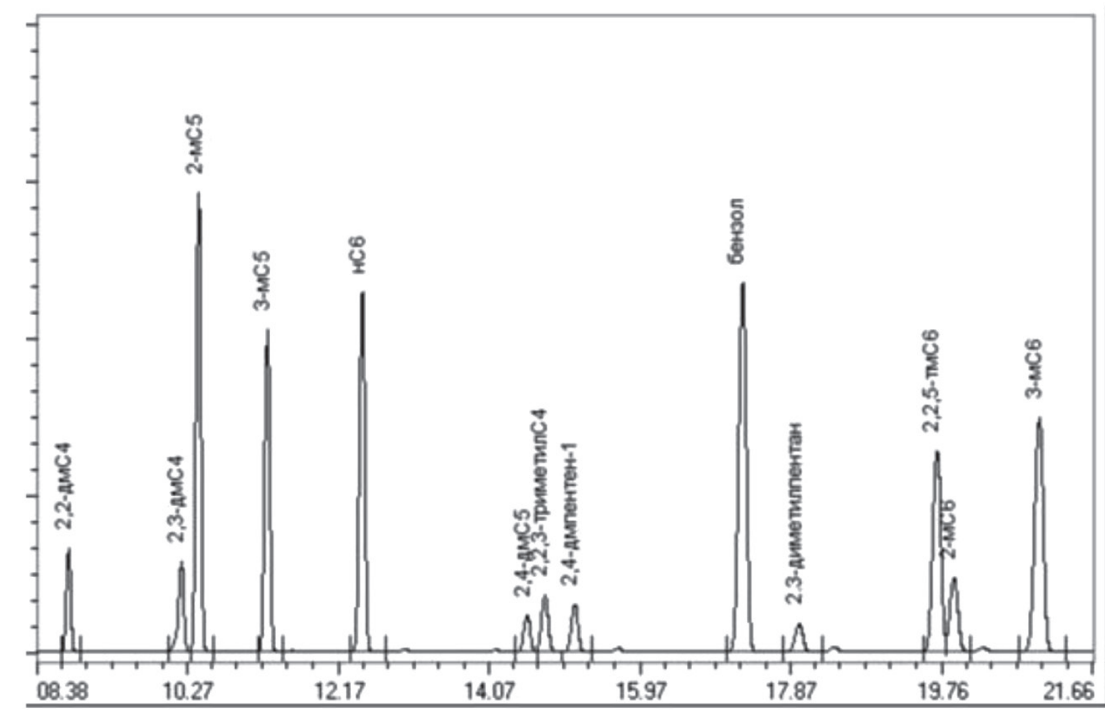

F ig. 4 - Typical chromatogram of the initial gasoline fraction "hydrogenate": 2.2-dimethyl $C_{4}(8.38 \mathrm{~min}) ; 2.3$-dimethyl $C_{4}(10.2 \mathrm{~min}) ; 2$-methyl $C_{5}(10.4 \mathrm{~min})$; 3-methyl $C_{5}$ $(11.22 \mathrm{~min}) ; n-C_{6}(12.3 \mathrm{~min}) ; 2,2,3-$ trimethyl $C_{4}(14.97 \mathrm{~min}) ; 2,4$-dimethylpentene-1 $(15.2 \mathrm{~min})$; benzene $(17.19 \mathrm{~min}) ; 2,3$-dimethylpentane $(17.95 \mathrm{~min}) ; 2,2,5$-trimethyl $C_{6}$ (19.6 min); 2-methyl $C_{6}(19.95 \mathrm{~min}) ; 3-$ methyl $C_{6}(21.1 \mathrm{~min})$

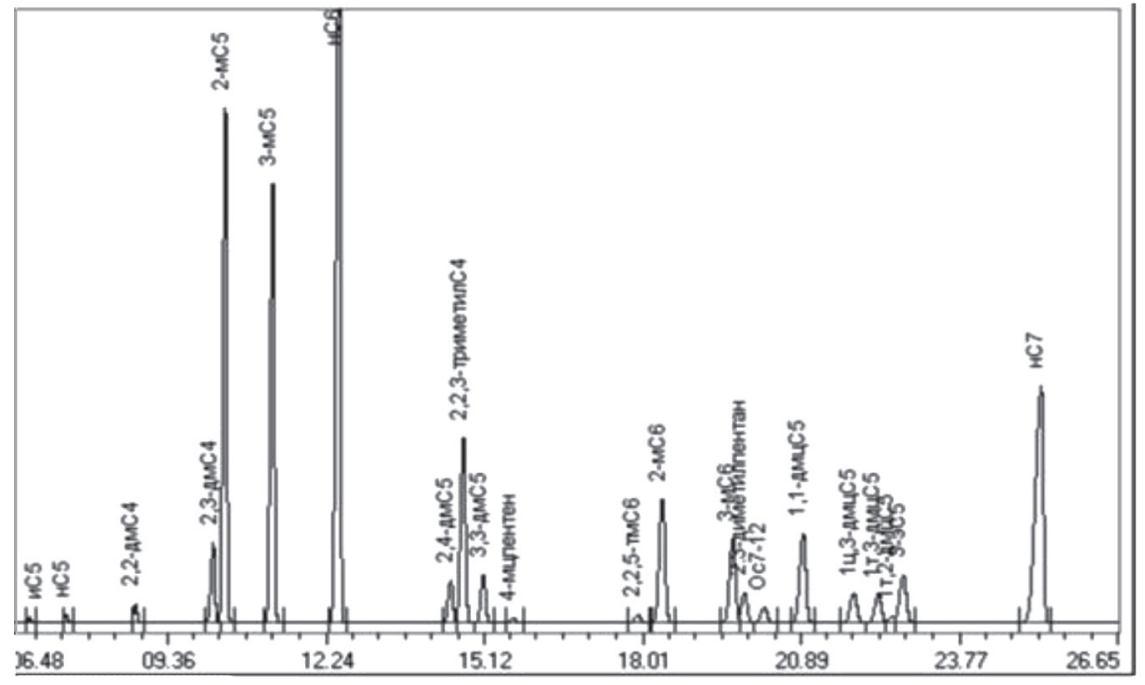

Fig. 5 - Typical chromatogram of the final product of gasoline fraction hydrogenation: 2.2-dimethyl $C_{4}(8.38 \mathrm{~min}) ; 2,3$-dimethyl $C_{4}(10.2 \mathrm{~min}) ; 2$-methyl $C_{5}(10.4 \mathrm{~min})$; 3-methyl $C_{5}(11.22 \mathrm{~min}) ; n-C_{6}(12.3 \mathrm{~min}) ; 2,2,3$-trimethyl $C_{4}(14.97 \mathrm{~min}) ; 2$,4-dimethylpentene-1 (15.2 min); benzene $(17.19 \mathrm{~min})$ - a peak is absent; 2-methyl $C_{6}(18.2 \mathrm{~min})$; 1.1-dimethylcyclo $C_{5}(20.89 \mathrm{~min}) ; 1$-cyclo-3-dimethylcyclo $C_{5} ; 1,2$-dimethylcyclo- $C_{5}$ (21.5 min-22.5 min); $n-C_{7}(25.6 \mathrm{~min})$ 

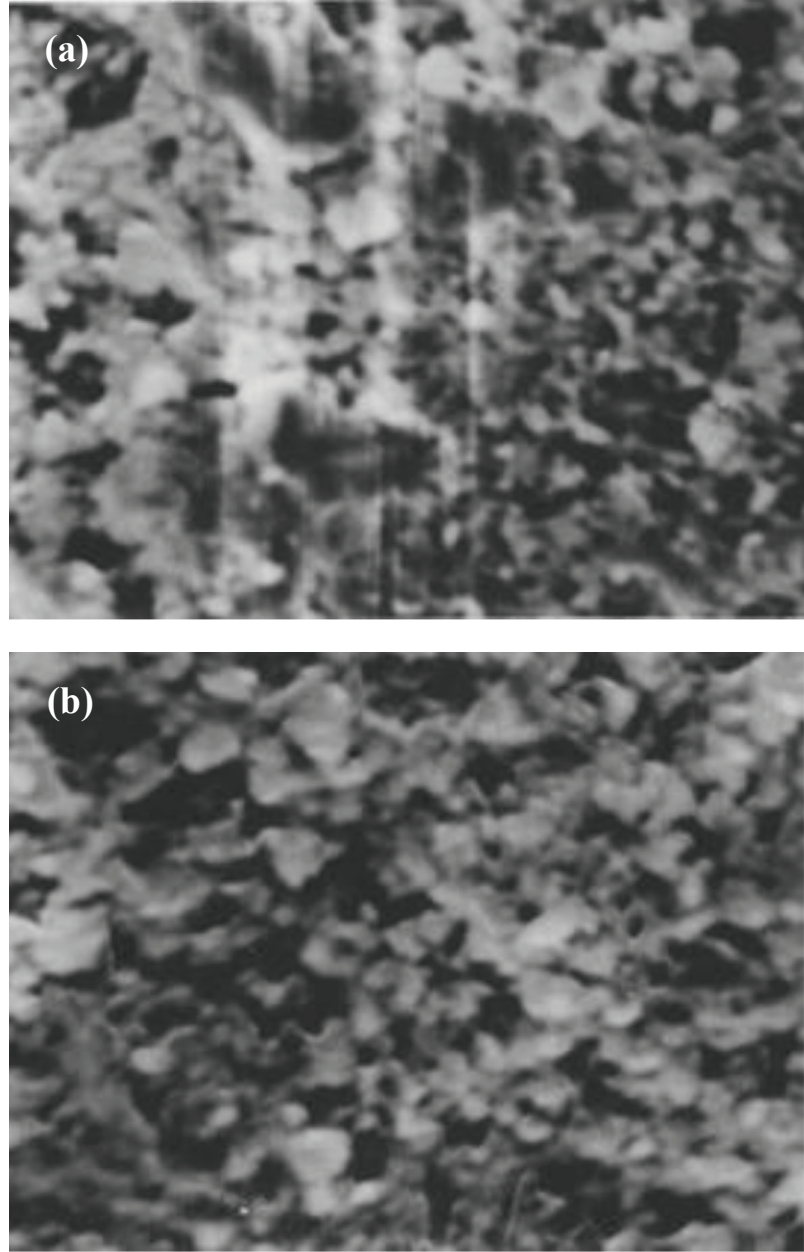

Fig. 6 - SEM images of different catalysts: a) $2 \%$ Pt-Rh $(9: 1) / \mathrm{Al}_{2} \mathrm{O}_{3}$ b) $2 \% \mathrm{Pt}-\mathrm{Pd}(9: 1) / \mathrm{Al}_{2} \mathrm{O}_{3}$

been used in this work. It was found that the octane number of gasoline fractions before hydrogenation and after hydrogenation did not change: by the research method it was 94 ("Stable catalysate") and 60 (the Straight-run gasoline), and by the motor method 82.6-82.7 and 50.0, respectively. This indicates that at catalytic hydrodearomatization, the octane number of gasoline fractions is not reduced. Thus, the octane number of gasoline fractions, as shown by the results of the analysis, is not changed after catalytic hydrogenation.

\section{Research of catalysts by means of physical and chemical methods of investigation}

The specific surface area of the catalysts is 175 $-290 \mathrm{~m}^{2} \mathrm{~g}^{-1}$ depending on the nature of the active metal. Addition of the second metal slightly reduces the specific area. Diameter of the pores of monometallic catalysts is changed from 5 to $14 \AA$ depending on the metal, and of bimetallic - from 12.0 to $25.0 \AA$. The volume of the pores of catalysts represent: Pt-Pd(1:1)/ $/ \mathrm{Al}_{2} \mathrm{O}_{3} S_{\mathrm{w}}=318.33 \mathrm{~mL} \mathrm{~g}{ }^{-1} ; \mathrm{Rh}-\mathrm{Pd}(1: 1) /$
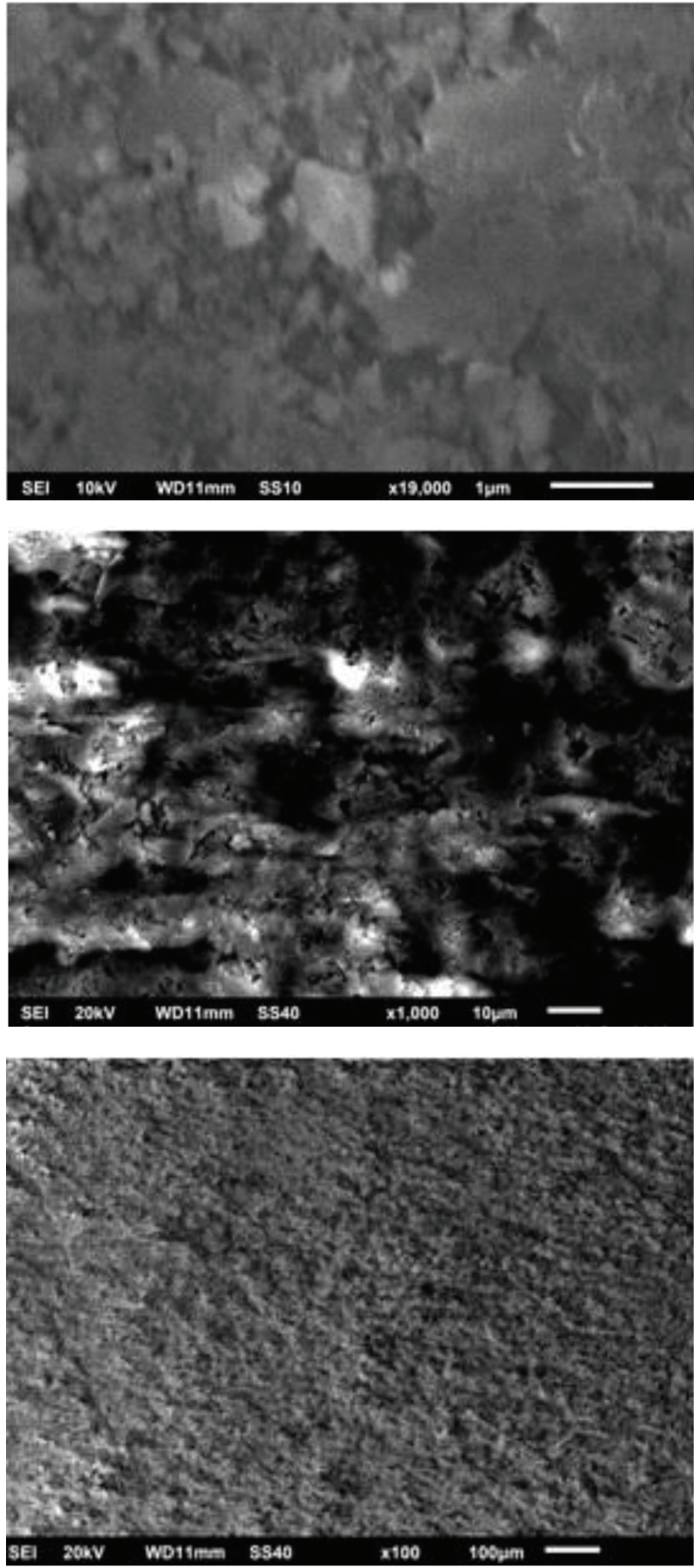

Fig. 7 - SEM images of catalyst Rh-Pt (9:1)/Al $\mathrm{O}_{3}$ at different magnifications

$\mathrm{Al}_{2} \mathrm{O}_{3} S_{\mathrm{w}}=282.25 \mathrm{~mL} \mathrm{~g}^{-1} ; \mathrm{Rh}-\mathrm{Pt}(9: 1) / \mathrm{Al}_{2} \mathrm{O}_{3} S_{\mathrm{w}}=$ $313.28 \mathrm{~mL} \mathrm{~g}{ }^{-1} ; \mathrm{Rh}-\mathrm{Pd}(9: 1) / \mathrm{Al}_{2} \mathrm{O}_{3} S_{\mathrm{w}}=213.39 \mathrm{~mL} \mathrm{~g}^{-1}$; $\mathrm{Pd}-\mathrm{Ru}(1: 1) / \mathrm{Al}_{2} \mathrm{O}_{3} S_{\mathrm{w}}=297.09 \mathrm{~mL} \mathrm{~g}^{-1}$.

By the method of scanning electron microscopy, the surfaces of the catalysts were investigated. Catalysts on the basis of $\mathrm{Pd}-\mathrm{Pt} / \gamma-\mathrm{Al}_{2} \mathrm{O}_{3}$ and $\mathrm{Pt}-\mathrm{Rh} /$ $\mathrm{Al}_{2} \mathrm{O}_{3}$ have structure consisting of fine-grained particles with a size of $20-25 \AA$, the dense large particles with a size of $50 \AA$ (Fig. 6) in a small amount 


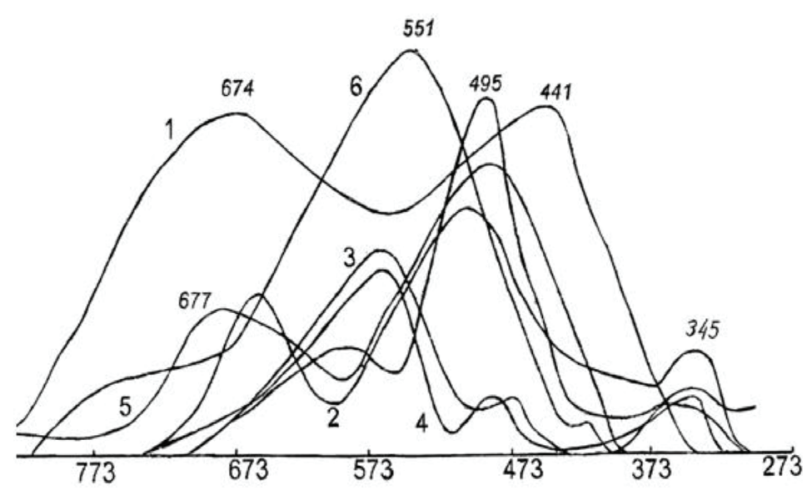

Fig. 8 - Thermal desorption of the catalysts with different compositions in condition of linear programmed increase in temperature of the catalysts from 293 to $1023 \mathrm{~K} ; 1-5 \% \mathrm{Rh} /$ $\mathrm{Al}_{2} \mathrm{O}_{3} ; 2-2 \% \mathrm{Pd}_{\mathrm{A}} \mathrm{Al}_{2} \mathrm{O}_{3} ; 3-5 \% \mathrm{Rh}-\mathrm{Pd}(1: 1) / \mathrm{Al}_{2} \mathrm{O}_{3} ; 4-5 \%$ $\mathrm{Rh}-\mathrm{Pt}(1: 1) / \mathrm{Al}_{2} \mathrm{O}_{3} ; 5-5 \% \mathrm{Rh}-\mathrm{Pd}(9: 1) / \mathrm{Al}_{2} \mathrm{O}_{3} ; 6-5 \% \mathrm{Rh}-\mathrm{Pt}$ $(9: 1) / \mathrm{Al}_{2} \mathrm{O}_{3}$

are also found. Clearly, the diffuse rings corresponding to various metals are noticeable in the images. The uniform distribution of the homogeneous particles of the catalyst on a catalyst surface is shown. In Fig. 7, images of different increase in $\mathrm{Rh}$ $\mathrm{Pt}(9: 1) / \mathrm{Al}_{2} \mathrm{O}_{3}$ catalyst are presented. The uniform surface of the carrier on which agglomerates of the active metals are visible is presented.

Hydrogen TPD data demonstrate that, in the case of supported catalysts, the bimetallic number of forms of the sorbed hydrogen, characteristic for each of the components, remains constant, while the ratio between the hydrogen forms with the change in catalyst composition vary considerably (Fig. 8). Hydrogen from Pd-Pt-catalysts supported on $\gamma-\mathrm{Al}_{2} \mathrm{O}_{3}$ is desorbed in the form of dissolved and strongly adsorbed. When addition $\mathrm{Pd}$ and $\mathrm{Pt}$ into composition of the Rh-catalyst there were noticed: a shift in the position of peaks of hydrogen desorption; a change in a ratio of a share of different forms of hydrogen. The high selectivity of $5 \% \mathrm{Rh}-\mathrm{Pt}$ $(9: 1) / \mathrm{A}_{2} \mathrm{O}_{3}$ is probably associated with the presence of a large share of hydrogen with an average energy bond with the surface.

The results of the physicochemical studies of the synthesized catalysts are consistent with the literature data ${ }^{19-24}$.

\section{Conclusions}

The hydrogenation of the aromatic rings in two gasoline fractions of LLP "Atyrau Oil Refinery" (Kazakhstan): 1 - "hydrogenate" pos.11-SN-002 KU GBD, 2 -"stable catalysate" was studied. In the hydrogenation of gasoline, Pt-Rh-catalysts on the carrier $\gamma-\mathrm{Al}_{2} \mathrm{O}_{3}$ showed the greatest activity. Catalytic hydrogenation allows reduction of aromatic con- tent (totally) for "hydrogenate" fraction to $0.6-4.64 \%$ (in initial gasoline - $11.2 \%$ ), and complete exclusion of benzene from the final test $(100 \%$ conversion), or reduction of its quantity to $0.06 \%$ (in initial sample $-2.54 \%$ ). For the "stable catalysate", the content of benzene in the initial state was 5.17 wt. $\%$, and after hydrogenation, the benzene content was 0.15 wt. $\%$, i.e. benzene conversion was equal to $97.0 \%$. The octane number of gasoline fractions before hydrogenation and after hydrogenation were not reduced: by the research method it was 94 (stable catalysate), and by the motor method $82.6-82.7$.

\section{References}

1. Lefeber, R., The Practice of the Compliance Committee under the Kyoto Protocol to the United Nations Framework Convention on Climate Change, Non-Compliance Procedures and Mechanisms and the Effectiveness of International Environmental Agreements, (2006-2007), 303. doi: https://doi.org/10.1007/978-90-6704-557-5 18.

2. Gal'perin, L. B., Fedorov, A. P., Maslyanskii, G. N., Mel'nikova, N. P., Gol'dberg, A. Ya., Single-stage process for hydroderomatization of jet fuels, Chemistry and Technology of Fuels and Oils 11(1974) 873. doi: https://doi.org/10.1007/bf00724022

3. Yurkina, O. V., Krayev, Y. L., Hydrogenation of aromatic hydrocarbons of petroleum middle distillates on palladium catalysts, Refining and Petrochemicals 11 (2002) 8.

4. Goundani, K., Papadopoulou, Ch., Kordulis, Ch., Benzene elimination from reformate gasoline by high pressure hydrogenation in a fixed-bed reactor, Reaction Kinetics and Catalysis Letters 1(2004)149.

doi: https://doi.org/10.1023/B:REAC.0000028816.68260.6b

5. Sassykova, L. R., Chemistry and physics of petroleum, gas and coal, Qazaq University, Almaty, 2017, 196.

6. Sendilvelan, S., Bhaskar, K., Nallusamy, S., Experimental investigation on cerium oxide nanoparticles with alumina catalytic converter to increase emission conversion efficiency in automobiles, Rasayan J. Chem. 2 (2017)454. doi: https://doi.org/10.7324/RJC.2017.1021685

7. Sendilvelan, S., Bhaskar, K., Aluminium phosphate supported copper phosphate catalytic converter to reduce nitrous oxides and particulate matter from engine emission, Oriental J. Chem. 4 (2017) 2111.

8. Hancsók, J., Marsi, G., Kasza, T., Kalló, D., Hydrogenation of the aromatics and olefins in FCC gasoline during deep desulphurisation, Topics in Catalysis 54 (2011) 1102. doi: https://doi.org/10.1007/s11244-011-9731-9.

9. Éigenson, A. S., Berg, G. A., Kirillov, T. S., Kulinich, G. M., Skundina, L. Ya., Kolbina, L. I., Production of high-quality catalytic reforming feed stock by deep hydrogenation of secondary-process gasolines, Chem. Technol. Fuels Oils 5 (1969) 237. doi: https://doi.org/10.1007/BF00730176

10. Baiseitov, D. A., Tulepov, M. I., Sassykova, L. R., Gabdrashova, Sh. E., Magazova, A. N., Dalelkhanuly, O., Kudyarova, Zh. B., Mansurov, Z. A., Catalytic hydrogenation of coal of the kazakhstan fields in presence of polymers, Bulgarian Chem. Commun. 3 (2017) 600. 
11. Aubakirov, Y. A., Sassykova, L. R., Nalibayeva, A. M., Dossumov, K., Tashmukhambetova, Z. K., Zhumakanova, A. S., Zhussupova, A. K., Zhakirova, N. K., Synthesis and testing of catalysts for decrease of toxic emissions of vehicles, Oriental J. Chem. 6 (2017) 3130 . doi: https://doi.org/10.13005/ojc/330655

12. Baiseitov, D., Tulepov, M., Sassykova, L., Gabdrashova, Sh., Kudaibergenov, K., Mansurov, Z., Physicomechanical properties of petrosorbents of the phytogenesis, Revue Roumaine de Chimie 3 (2017) 249

13. Baiseitov, D. A., Gabdrashova, Sh. E., Magazova, A. N., Dalelkhanuly, O., Kudyarova, Zh. B., Tulepov, M. I., Sassykova, L. R., Mansurov, Z. A., Hydrogenation of coal of "Karazhira" field: optimal catalysts and thermogravimetric researches, Int. J. Chem. Sci. 1 (2016) 244.

14. Baiseitov, D. A., Gabdrashova, Sh. E., Akylbai, A. K., Dalelkhanuly, O., Kudyarova, Zh. B., Sassykova, L. R., Tulepov, M. I., Mansurov, Z. A., Obtaining of liquid fuel from coal in the presence of the polymers, Int. J. Chem. Sci.1 (2016) 261.

15. Gasoline for automobiles. Determination of individual and group hydrocarbon composition by capillary gas chromatography, GOST R52714-2007, 2007. http://gostexpert.ru/gost/gost-51946-2002

16. Sasykova, L. R., Kasenova, D. Sh., Masenova, A. T., Bizhanov, $F$. $B$, Chromatographic analysis of nitro compounds and their reduction products, Russian Journal of Applied Chemistry 8 (1998) 1401.

17. ASTM D 4057:95, Guide to manual sampling of oil and oil product; ASTM D4057 - 12, Standard Practice, ASTM
(05.02), Petroleum Products, Liquid Fuels, and Lubricants (II):D3711-D6122(2000)

www.astm.org/BOOKSTORE/BOS/0502.htm.

18. Practice for Manual Sampling of Petroleum and Petroleum Products Standard, D02 Committee. doi: https://doi.org/10.1520/d4057

19. Bertolacini, R. J., Valence State of Platinum-Alumina Catalysts, Nature 4808 (1961) 1179. doi: https://doi.org/10.1038/1921179a0

20. Yasuda, H., Kameoka, T., Sato, T., Kijima, N., Yoshimura, Y., Sulfur-tolerant $\mathrm{Pd}-\mathrm{Pt} / \mathrm{Al}_{2} \mathrm{O}_{3}-\mathrm{B}_{2} \mathrm{O}_{3}$ catalyst for aromatic hydrogenation, Applied Catalysis A: General. 2 (1999) 199. doi: https://doi.org/10.1016/s0926-860x(99)00193-3.

21. Orozco, J. M., Webb, G., The adsorption and hydrogenation of benzene and toluene on alumina- and silica- supported palladium and platinum catalysts, Applied Catalysis $\mathbf{1}$ (1983) 67. doi: https://doi.org/10.1016/0166-9834(83)80189-4.

22. Poondi, D., Vannice, M. A., Competitive hydrogenation of benzene and toluene on palladium and platinum catalysts, Journal of Catalysis 2 (1996) 742 doi: https://doi.org/10.1006/jcat.1996.0236.

23. Fan, X., Lapkin, A. A., Plucinski, P. K., Liquid phase hydrogenation in a structured multichannel reactor, Catalysis Today 147 (2009) S313. doi. https://doi.org/10.1016/j.cattod.2009.07.048

24. Louis, C., Chemical preparation of supported bimetallic catalysts. Gold-based bimetallic, a Case study, Catalysts 6 (2016) 110. doi: https://doi.org/10.3390/catal6080110 